\title{
Photorhabdus temperata subsp. cinerea subsp. nov., isolated from Heterorhabditis nematodes
}

\author{
Tímea Tóth and Tamás Lakatos \\ Research and Extension Centre for Fruit Growing, Vadastag 2, H-4244 Újfehértó, Hungary
}

Correspondence

Tamás Lakatos

tamas.lakatos@gmail.com

\begin{abstract}
During the characterization of symbiotic bacteria of Hungarian entomopathogenic nematode isolates, a number of bacteria (including strain $3107^{\top}$ ) isolated from Heterorhabditis downesi and Heterorhabditis megidis showed only moderate 16S rRNA gene sequence similarity to the type strains of all described Photorhabdus species and subspecies. On the basis of the 16S rRNA gene sequence, the phylogenetic relationships of these isolates were uncertain, because of the low bootstrap values. Using gyrB sequences for phylogenetic analysis, these isolates were shown to be part of the species Photorhabdus temperata, with clear separation from both Palaearctic and American strains (phylogenetic distances are 6.9 and $7.9 \%$, respectively). Physiological properties and carbon-source utilization profiles supported the phylogenetic position of these strains; therefore, a novel subspecies, Photorhabdus temperata subsp. cinerea subsp. nov. is proposed, with the type strain $3107^{\top}\left(=\mathrm{DSM} 19724^{\top}=\right.$ NCAIM B $\left.02271^{\top}\right)$.
\end{abstract}

The bacterial genus Photorhabdus, members of which are associated symbiotically with entomopathogenic nematodes in the genus Heterorhabditis, was proposed by Boemare et al. (1993) with the transfer of Xenorhabdus luminescens (Thomas \& Poinar, 1979) to a new genus. After phylogenetic evidence of the taxonomic heterogeneity of Photorhabdus luminescens was provided by Szállás et al. (1997), Fischer-Le Saux et al. (1999) described the three present species of the genus (Photorhabdus asymbiotica, $P$. luminescens and Photorhabdus temperata), with three subspecies of $P$. luminescens ( $P$. luminescens subsp. akhurstii, $P$. luminescens subsp. laumondii and $P$. luminescens subsp. luminescens) and one (illegitimate) subspecies of $P$. temperata ('P. temperata subsp. temperata'). Akhurst et al. (2004) described two subspecies of $P$. asymbiotica ( $P$. asymbiotica subsp. australis and $P$. asymbiotica subsp. asymbiotica), while Hazir et al. (2004) described two further subspecies of $P$. luminescens ( $P$. luminescens subsp. kayaii and P. luminescens subsp. thracensis).

During the characterization of symbiotic bacteria of Hungarian entomopathogenic nematode isolates, about $32 \%$ of bacteria (including strain $3107^{\mathrm{T}}$ ) isolated from infective juveniles of Heterorhabditis nematodes produced a grey pigment on NA, LB (both from Merck) or TSA (30 g soy peptone, $5 \mathrm{~g}$ yeast extract and $12 \mathrm{~g}$ agar-agar in $1000 \mathrm{ml}$ water) plates, colouring the culture media. This

The GenBank/EMBL/DDBJ accession numbers for the 16S rRNA and gyrB gene sequences of strain $3107^{\top}$ are EU136626 and EU053168, respectively.

Details of the sequences used for phylogenetic analysis and a $16 \mathrm{~S}$ rRNA gene sequence-based neighbour-joining tree are available as supplementary material with the online version of this paper. trait is not characteristic of any described Photorhabdus species or subspecies.

In total, 23 isolates with this special feature were used for morphological and biochemical tests, and three isolates (isolates $3107^{\mathrm{T}}, 3014$ and 3240 ) were selected as typical representatives of the taxon based on colony morphology and carbon-source utilization patterns. The 23 isolates originated from five different geographical locations in Hungary, at least $50 \mathrm{~km}$ apart. The nematode hosts were Heterorhabditis downesi (eight bacterial isolates) and Heterorhabditis megidis (15 bacterial isolates).

Cell morphology was observed under a Zeiss Axiostar light microscope at $\times 1000$ magnification, with cells grown for 34 days on TSA at $28{ }^{\circ} \mathrm{C}$. The $16 \mathrm{~S}$ rRNA and gyrB genes of isolates $3107^{\mathrm{T}}, 3014$ and 3240 were analysed as described by Tailliez et al. (2006) and Akhurst et al. (2004), respectively. Phylogenetic and molecular evolutionary analyses were conducted using MEGA version 4 (Tamura et al., 2007) after multiple alignment of sequences by CLUSTAL_X (Thompson et al., 1997). Distances were calculated using Kimura's twoparameter model, while clustering with the neighbourjoining method was determined by using bootstrap values based on 1000 replications. The details of sequences used for the phylogenetic analyses are listed in Supplementary Table S1 (available in IJSEM Online). Physiological properties and carbon-source utilization profiles were analysed with API 20E strips (bioMérieux) and Biolog GN microplates as described previously (Fischer-Le Saux et al., 1999; Hazir et al., 2004).

Based on analysis of 23 isolates (including $3107^{\mathrm{T}}, 3014$ and 3240), all strains grow well on TSA, LB agar and NA plates. Colonies of the strains are highly bioluminescent. Young (1-3 days old) colonies on NA plates are salmon-coloured 
or light grey. A characteristic grey coloration is visible in the growth medium around older colonies (2-4 days), and the colour of liquid culture media (LB or tryptic soy broth) is also grey. The upper temperature for growth is $34-35{ }^{\circ} \mathrm{C}$ $\left(\right.$ strain $3107^{\mathrm{T}}$ ) or $36-37^{\circ} \mathrm{C}$ (strain 3014 ). The optimal growth temperature is around $28{ }^{\circ} \mathrm{C}$ (both on agar plates and in liquid culture), but a phase shift to a secondary form variant (Akhurst, 1980) is very common at this temperature. At lower temperature $\left(20^{\circ} \mathrm{C}\right)$ in liquid culture, the phase shift is rare. In tests with API 20E strips and Biolog GN2 plates, the most important distinguishing biochemical characteristics of the taxon (based on 23 isolates) are the ability to use myo-inositol and maltose (distinct from $P$. temperata XINach ${ }^{\mathrm{T}}$ ) or xylitol and DL-lactic acid (distinct from all Photorhabdus species and subspecies) as a sole carbon source (Table 1). Based on 16S rRNA gene sequences, the separation of this proposed taxon from described species and subspecies of Photorhabdus is unambiguous, but the attachment of the genus to the phylogenetic tree is uncertain because of the low bootstrap values (Supplementary Fig. S1). The average similarity to other taxa in the genus is 95.8-97.2\% (Kimura's twoparameter model; 1414 sites). In contrast to the $16 \mathrm{~S}$ rRNA gene sequence, the gyrB gene provides more useful data for investigating intrageneric phylogenies of Photorhabdus (Akhurst et al., 2004). Using gyrB sequences for phylogenetic analysis, the proposed taxon was shown to be part of the species Photorhabdus temperata (Fig. 1). The average similarity to Palaearctic isolates $\left(\mathrm{XINach}^{\mathrm{T}}\right.$, HL81, HW79 and XILit; $P$. temperata subsp. temperata) is $93.1 \%$, while the similarity to American isolates (Meg, Habana, C1; $P$. temperata) is $92.1 \%$. The similarity to the other taxa in the genus is $88.0-90.7 \%$ (Kimura's two-parameter model; 994 sites).

Creation of this novel subspecies also has the effect of automatically creating the subspecies Photorhabdus temperata subsp. temperata Fischer-Le Saux et al. 1999.

\section{Description of Photorhabdus temperata subsp. cinerea subsp. nov.}

Photorhabdus temperata subsp. cinerea (ci.ne.re'a. L. fem. adj. cinerea resembling ashes, because this subspecies produces a grey pigment that colours the growing medium and infected insects).

Cells are large rods, $4.8(2-7) \times 1.0 \mu \mathrm{m}$. Inclusion bodies are present. Highly bioluminescent. Colonies on nutrient agar are salmon pink or light grey in colour and mucoid; there is grey coloration in the growth medium around the colonies. Adsorbs dye on NBTA and MacConkey plates. Maximum temperature for growth is $34-35{ }^{\circ} \mathrm{C}\left(\right.$ strain $\left.3107^{\mathrm{T}}\right)$ or $36-$ $37^{\circ} \mathrm{C}$ (strain 3014). Annular haemolysis is present on sheepblood agar. Negative for $o$-nitrophenyl $\beta$-D-galactopyranoside hydrolysis and the Voges-Proskauer test. Gelatinase activity is present. Main biochemical characteristics (including differentiating characters from other Photorhabdus species and subspecies) are indicated in Table 1.

The type strain is $3107^{\mathrm{T}}\left(=\right.$ DSM $19724^{\mathrm{T}}=$ NCAIM B $\left.02271^{\mathrm{T}}\right)$, isolated from the intestine of the entomopathogenic nematode Heterorhabditis downesi collected from a deciduous forest at Ásotthalom, Hungary. Other strains have been isolated from $H$. downesi and $H$. megidis, collected from five different geographical locations in Hungary.

Table 1. Phenotypic characters that differentiate the proposed novel subspecies from described taxa of Photorhabdus

Strains: 1, P. asymbiotica subsp. asymbiotica $3265-86^{\mathrm{T}} ; 2$, P. asymbiotica subsp. australis $9802892^{\mathrm{T}} ; 3$, P. luminescens subsp. akhurstii FRG04 ${ }^{\mathrm{T}}$; 4 , P. luminescens subsp. kayaii $1121^{\mathrm{T}} ; 5$, P. luminescens subsp. laumondii $\mathrm{TT} 01^{\mathrm{T}} ; 6$, P. luminescens subsp. luminescens $\mathrm{Hb}^{\mathrm{T}}$; 7, P. luminescens subsp. thracensis $39-8^{\mathrm{T}} ; 8$, P. temperata XINach ${ }^{\mathrm{T}} ; 9,23$ strains of $P$. temperata subsp. cinerea subsp. nov. [percentages giving a positive reaction (with the exception of the maximum growth temperature); results for isolate $3107^{\mathrm{T}}$ are in parentheses]. Data are from Akhurst et al. (2004) (columns 1 and 2), Hazir et al. (2004) (columns 4-7) and this study. +, Positive; -, negative; ND, no data available.

\begin{tabular}{|c|c|c|c|c|c|c|c|c|c|}
\hline Characteristic & 1 & 2 & 3 & 4 & 5 & 6 & 7 & 8 & 9 \\
\hline Maximum growth temperature $\left({ }^{\circ} \mathrm{C}\right)$ & 38 & 40 & 38 & 36 & 36 & 38 & 35 & 34 & 35 \\
\hline Indole production & - & - & + & + & + & + & - & - & $4(-)$ \\
\hline DNase & - & + & - & + & + & - & + & + & $100(+)$ \\
\hline Urease & + & - & + & + & + & - & + & - & $35(-)$ \\
\hline Tryptophan deaminase & - & - & - & ND & - & - & ND & - & $57(-)$ \\
\hline Growth on Simmons' citrate & + & + & + & + & - & + & + & + & $87(+)$ \\
\hline Annular haemolysis on sheep-blood agar & + & + & + & + & - & + & + & + & $100(+)$ \\
\hline \multicolumn{10}{|l|}{ Utilization of: } \\
\hline L-Fucose & - & - & + & - & - & + & - & + & $96(+)$ \\
\hline L-Histidine & + & - & - & - & + & + & + & + & $100(+)$ \\
\hline myo-Inositol & - & + & + & + & + & + & - & - & $100(+)$ \\
\hline DL-Lactate & - & - & + & - & - & - & - & - & $87(+)$ \\
\hline D-Mannitol & - & - & + & - & - & + & - & - & $0(-)$ \\
\hline Maltose & + & + & + & + & + & + & + & - & $100(+)$ \\
\hline Xylitol & - & - & - & - & - & - & - & - & $100(+)$ \\
\hline
\end{tabular}




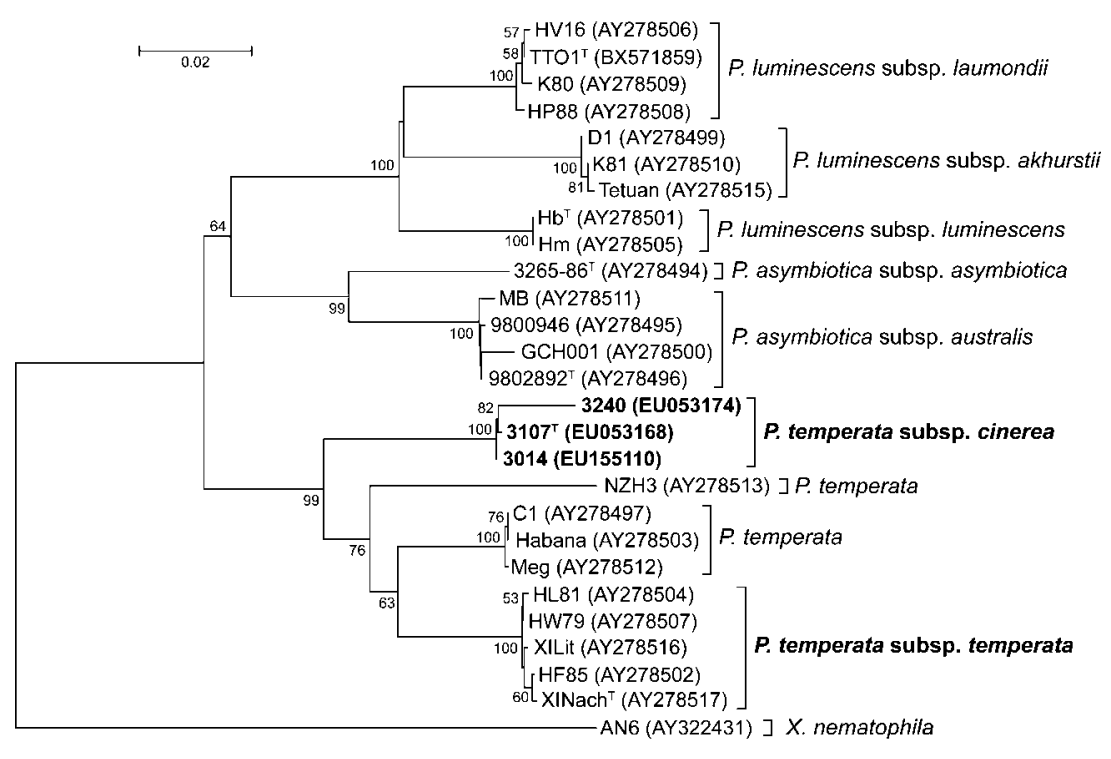

Fig. 1. Phylogenetic relationships within the genus Photorhabdus based on the analysis of gyrB gene sequences. Evolutionary history was inferred using the neighbour-joining method (Saitou \& Nei, 1987). The optimal tree with the sum of branch lengths of 0.50650502 is shown. Percentages of replicate trees in which the associated taxa clustered together in the bootstrap test (1000 replicates) are shown next to branches (Felsenstein, 1985). The tree is drawn to scale, with branch lengths in the same units as those of the evolutionary distances used to infer the phylogenetic tree. Evolutionary distances were computed using Kimura's two-parameter method (Kimura, 1980) and are expressed as numbers of base substitutions per site. Positions containing gaps and missing data were eliminated from the dataset, giving a total of 994 positions in the final dataset. Phylogenetic analyses were conducted in MEGA4 (Tamura et al., 2007).

\section{Acknowledgements}

This work was supported by the Hungarian State and the European Union during the project GVOP-3.1.1-2004-05-0223/3.0 and the Hungarian North-Great Plain Region through the Baross Gábor Regional Innovation Programme.

\section{References}

Akhurst, R. J. (1980). Morphological and functional dimorphism in Xenorhabdus spp., bacteria symbiotically associated with the insect pathogenic nematodes Neoplectana and Heterorhabditis. J Gen Microbiol 121, 303-309.

Akhurst, R. J., Boemare, N. E., Janssen, P. H., Peel, M. M., Alfredson, D. A. \& Beard, C. E. (2004). Taxonomy of Australian clinical isolates of the genus Photorhabdus and proposal of Photorhabdus asymbiotica subsp. asymbiotica subsp. nov. and P. asymbiotica subsp. australis subsp. nov. Int J Syst Evol Microbiol 54, 1301-1310.

Boemare, N. E., Akhurst, R. J. \& Mourant, R. G. (1993). DNA relatedness between Xenorhabdus spp. (Enterobacteriaceae), symbiotic bacteria of entomopathogenic nematodes, and proposal to transfer Xenorhabdus luminescens to a new genus, Photorhabdus gen. nov. Int $J$ Syst Bacteriol 43, 249-255.

Felsenstein, J. (1985). Confidence limits on phylogenies: an approach using the bootstrap. Evolution 39, 783-791.

Fischer-Le Saux, M., Viallard, V., Brunel, B., Normand, P. \& Boemare, N. E. (1999). Polyphasic classification of the genus Photorhabdus and proposal of new taxa: P. luminescens subsp. luminescens subsp. nov., P. luminescens subsp. akhurstii subsp. nov., $P$. luminescens subsp. laumondii subsp. nov., $P$. temperata sp. nov., $P$. temperata subsp. temperata subsp. nov. and P. asymbiotica sp. nov. Int J Syst Bacteriol 49, 1645-1656.

Hazir, S., Stackebrandt, E., Lang, E., Schumann, P., Ehlers, R.-U. \& Keskin, N. (2004). Two new subspecies of Photorhabdus luminescens, isolated from Heterorhabditis bacteriophora (Nematoda: Heterorhabditidae): Photorhabdus luminescens subsp. kayaii subsp. nov. and Photorhabdus luminescens subsp. thracensis subsp. nov. Syst Appl Microbiol 27, 36-42.

Kimura, M. (1980). A simple method for estimating evolutionary rates of base substitutions through comparative studies of nucleotide sequences. J Mol Evol 16, 111-120.

Saitou, N. \& Nei, M. (1987). The neighbor-joining method: a new method for reconstructing phylogenetic trees. Mol Biol Evol 4, 406-425.

Szállás, E., Koch, C., Fodor, A., Burghardt, J., Buss, O., Szentirmai, A., Nealson, K. H. \& Stackebrandt, E. (1997). Phylogenetic evidence for the taxonomic heterogeneity of Photorhabdus luminescens. Int $J$ Syst Bacteriol 47, 402-407.

Tailliez, P., Pages, S., Ginibre, N. \& Boemare, N. E. (2006). New insight into diversity in the genus Xenorhabdus, including the description of ten novel species. Int J Syst Evol Microbiol 56, 2805-2818.

Tamura, K., Dudley, J., Nei, M. \& Kumar, S. (2007). MEGA4: molecular evolutionary genetics analysis (MEGA) software version 4.0. Mol Biol Evol 24, 1596-1599.

Thomas, G. M. \& Poinar, G. O., Jr (1979). Xenorhabdus gen. nov., a genus of entomopathogenic nematophilic bacteria of the family Enterobacteriaceae. Int J Syst Bacteriol 29, 352-360.

Thompson, J. D., Gibson, T. J., Plewniak, F., Jeanmougin, F. \& Higgins, D. G. (1997). The CLUSTAL_X windows interface: flexible strategies for multiple sequence alignment aided by quality analysis tools. Nucleic Acids Res 25, 4876-4882. 